Anais da Academia Brasileira de Ciências (2005) 77(1): 157-168

(Annals of the Brazilian Academy of Sciences)

ISSN 0001-3765

www.scielo.br/aabc

\title{
Coricladus quiteriensis gen. et sp. nov., a new conifer in Southern-Brazil Gondwana (Lower Permian, Paraná Basin)
}

\author{
ANDRÉ JASPER ${ }^{1}$, FRESIA RICARDI-BRANCO ${ }^{2}$ \\ and MARGOT GUERRA-SOMMER ${ }^{3}$ \\ ${ }^{1}$ Setor de Botânica e Paleobotânica do Museu de Ciências Naturais \\ do Centro Universitário da UNIVATES (SBP/MCN/UNIVATES) \\ Rua Avelino Tallini, 171 - 95900-000 Lajeado, RS, Brasil \\ ${ }^{2}$ Instituto de Geociências, Universidade Estadual de Campinas (UNICAMP) \\ Caixa Postal 6152 - 13083-970 Campinas, SP, Brasil \\ ${ }^{3}$ Instituto de Geociências, Universidade Federal do Rio Grande do Sul (IG/UFRGS) \\ Avenida Bento Gonçalves, 9.500 - 91051-970 Porto Alegre, RS, Brasil \\ Manuscript received on March 3, 2004; accepted for publication on July 21, 2004; \\ presented by ALCIDES N. SIAL
}

\begin{abstract}
A new taxon of conifers (Coricladus quiteriensis) is described based on megafloristic remains from the roofshale level at the Quitéria Outcrop (Rio Bonito Formation - Lower Permian - Southern Paraná Basin - Rio Grande do Sul - Brazil). This megafloristic community is included in the Botrychiopsis Zone - Botrychiopsis valida Sub-Zone (Kungurian/Roadian). The assemblage, preserved as impressions, do not present remains of epidermic characters, and is composed mainly of isolated vegetative branches with spirally disposed acicular leaves, presenting a conspicuous central vein and also isolated fertile branches with sparse and irregular leaves and terminal cones. Leafless principal branches, organically connected with sterile and fertile branches, are rare. Reproductive feminine scales, disposed in a plane, are organized in lax terminal cones on branches, composed by 4 (four) distal ovuliferous scales, and 8 (eight) elliptical-elongated anatropous seeds. Paleoecological data pointed out to a mesophylous to higrophylous habitat in swampy environments.
\end{abstract}

Key words: Coricladus quiteriensis, paleobotany, taxonomy, coniferopsida, Gondwana, Lower Permian.

\section{INTRODUCTION}

In Paleozoic Gondwana, the replacement of the Late Carboniferous flora by the glossopterid prevailing flora has been connected to a warming phase at the end of an icehouse stage (Gastaldo et al. 1996, Wnuk 1996, Anderson et al. 1999).

Conifers are common elements in the Glossopteris Flora, in taphofloras of wet lowland biomes of Early Permian, and sedimentary se-

Correspondence to: André Jasper

E-mail: ajasper@univates.br quences included in the Carboniferous/Early Triassic Megasequence of the Paraná Basin by Milani et al. (1998). This basal transgressive sedimentary section includes the lithostratigraphic units Itararé and Guatá Groups, comprising taphofloras preserved in lowland glaciocontinental sediments, and the Rio Bonito Formation, where are located most of the southern Brazil coal-bearing strata outcropping in isolated coal fields.

Detailed studies of roof-shale floras (GuerraSommer et al. 1991) in southernmost Paraná Basin show that there were significant changes in low- 
land floras across different areas and indicate vegetational heterogeneity within any coalfield. The presence of well preserved fragments of conifers, some of them corresponding to reproductive structures, in roof-shales, indicates to GuerraSommer et al. (2001) that group was an important element in lowland floras at the time of deposition of coal seams. In a reconstruction of a clastic swamp landscape unit by the analyses of a roof-shale flora at the Quitéria outcrop (UTM 0387516E and 6643183 N - Fig. 1) were identified three plant communities from a paleoenvironment associated to a lagoon/barrier system defined by Jasper and GuerraSommer (1999) based in previous regional stratigraphic studies (Della Fávera et al. 1994, Lopes and Lavina 1995, Holz 1997). The Arborescent Lycophyte Community was dominant; the Glossopteris Community, including also Cordaites, the understory vegetation (Rhodeopteridium, Botrychiopsis valida, herbaceous lycophytes), and the Conifer Community were common, but less significant, in that landscape unit.

This paper aims at describing and identifying the conifer material proceeding from the Quiteria roof-shale, to contribute to the understanding of the evolution of this group during the Upper Paleozoic, in Gondwanaland.

Taking into account the reproductive structure organized in lax cones on branches that are organized in lax cones, the forms here analyzed are considered as conifers sensu lato; in the present work are accepted the definitions of Biwas and Johry (1997) which consider as conifers the groups related to phylogeny of coniferophytes.

\section{MATERIALS AND METHODS}

Conifer fragments are concentrated and numerically predominant in lenticular facies within the roof-shale in a four meter transect of the outcropping area, at the same level as Brasilodendron stumps and Botrychiopsis valida fronds. This exposure provides a rare look at the short-term spatial heterogeneity in contemporaneous deposits. For stratigraphic details see Piccoli et al. (1991), Jasper and Guerra-Sommer (1998, 1999) and Jasper et al. (2003).

The plant assemblage here studied is included, by Jasper et al. (2003), in the Botrychiopsis Zone/ Botrychiopsis valida Sub-zone (Artinskian/Kungurian Interval). This age are confirmed by CazzuloKlepzig et al. (2002) with zircon radiometric dating of volcanic rocks interbedded in coal seams of Rio Bonito Formation in Southernmost Paraná Basin. Cazzulo-Klepzig et al. (2002) yielded an age of $267,1 \pm 3,4$ My which corresponds to the Kungurian/Roadian Interval. Reproductive branches and cones are preserved as impressions, but the preservation is exceptional and fine structural tridimensional details are available. The assemblage is composed by: a) dispersed, non-orientated vegetative and reproductive branches, branching up to third order, with spirally disposed acicular-lanceolate leaves; b) fertile isolated reproductive branches, with sparse, irregular acicular-lanceolate leaves and terminal cones; c) leafless principal branches in organic connection with fertile and vegetative reproductive branches branched up to third order, maintaining the same morphological parameters as the isolated specimens.

The material was analyzed using standard paleobotanical techniques of light microscope. Maceration techniques in leaves and cones did not yield epidermis and palynological material. The samples are stored in the Botany and Paleobotany Sector of the UNIVATES Natural Science Museum (PbU).

\section{SYSTEMATIC DESCRIPTION}

The systematic disposition of the plant fossils, adopted in the present paper, is the one used by Stewart and Rothwell (1993), Taylor and Taylor (1993), Biwas and Johry (1997) and Judd et al. (1999), who used cladistic methods to include the fossil forms in the group defined as modern plants.

Realm Plantae

Division Trachaeophyta

Class Coniferopsida

Order Voltziales? 


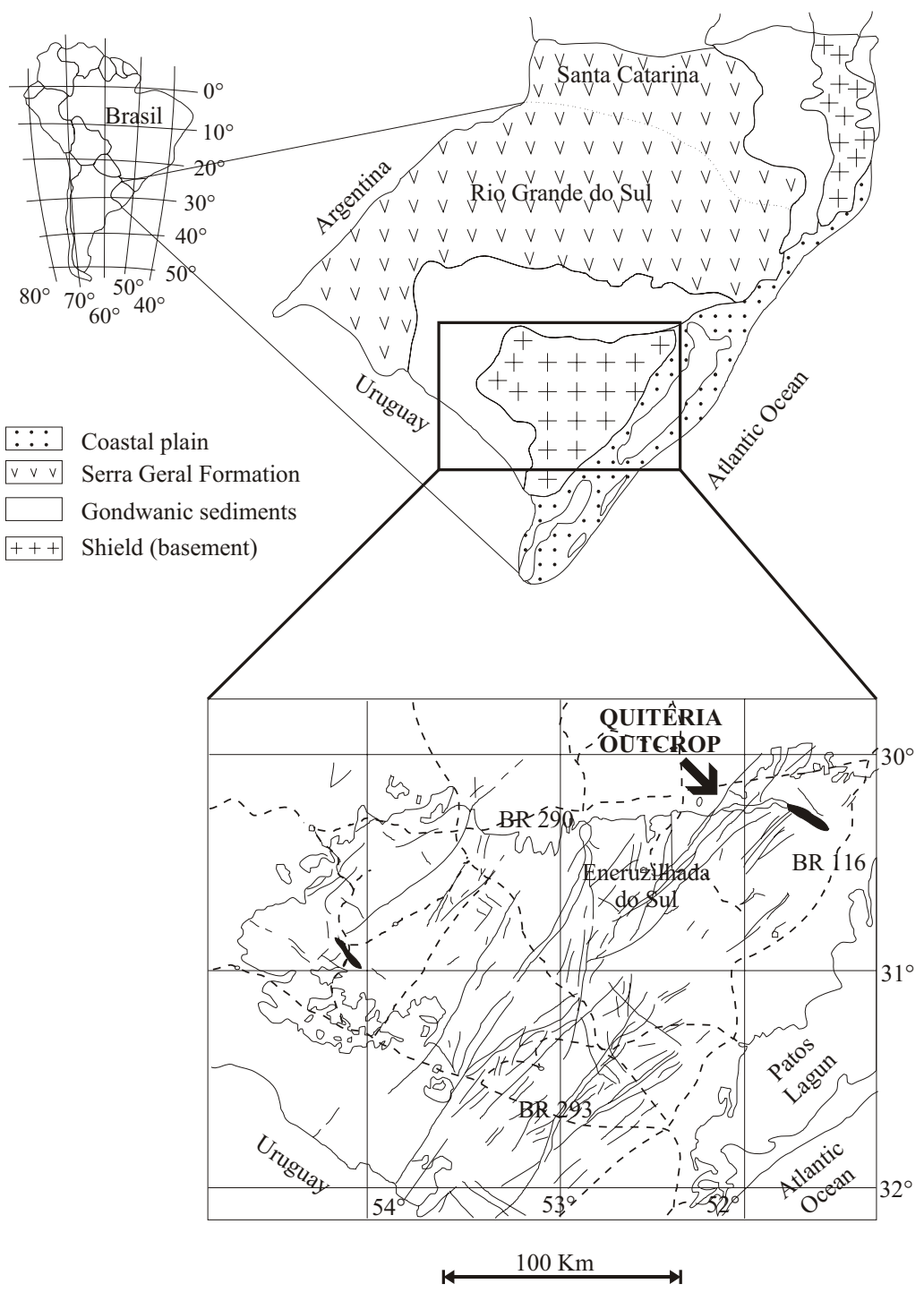

Fig. 1 - Localization of the Quitéria outcrop (adapted from Jasper et al. 2003, Fig. 2).

Coricladus gen. nov.

\section{Generic Diagnosis}

Compounded branches, leafless principal branches, bearing homomorphic, linear, sessil, straight basis, decurrent bracts, tapering gradually towards the apex. First order branches covered with helically disposed and overlapping leaves. Second and third order branches with the same leaf disposition observed in first order branches; at the apical portion there are globular densifications, formed by the whole of the leaves. Leaves are single, homomorphic, sessil, bifacial, acicular, slightly falciform with straight basis and acute apex. From the leafless principal branches, come branches with leaves of morphology identical to the one of the first, second and third order branches, although with scarce distribution. Apical portions of these branches bear 4 (four) distal-radial ovuliferous scales, forming a cone. All the ovuliferous scales with biphid apices and with adaxial torsion, elongating into a funicle porting two anatropous seeds. Cones composed of 
4 (four) scales and 8 (eight) elliptically elongated seeds.

- Type species: Coricladus quiteriensis sp. nov.

- Derivation of name: Genus from Guarani language, cori, pine tree, and from Greek cladus, branch. Specific epithet from the Quitéria outcrop, local of occurrence from this species.

- Holotype: PbU 074 (stored in the Botany and Paleobotany Sector of the UNIVATES Natural Science Museum).

- Paratypes: PbU 003, 005, 012, 018, 020, 022, 023, 025, 029, 030, 032, 034, 035, 037, 038, 039, 046, 047, 055, 056, 057, 060, 071, 072, 073, 075, 076, 078, 082, 091, 093, 094, 121, 133, 136, 162, 164, 165, 166, 169, 174, 175, 176, 183, 186, 187, 189, 191, 192, 197, 198, 200, 218, 217, 219, 220, 221, 222, 223, 225, 226, 228, 229, 237, 238, 239, 241, 242, 245, 248, 253, 260, 266, 267, 268, 271, 273, 298, 366, 367, 390, 392, 417, 418, 419 and 426.

- Type formation: Rio Bonito Formation, Permian (Sakmarian/Roadian Interval), Paraná Basin.

- Proceeds from: Quitéria Outcrop, Encruzilhada do Sul, RS.

\section{Coricladus quiteriensis sp. nov.}

(Fig. 3 and 5)

\section{Specific Diagnosis}

Compounded sterile branches, with three branching orders. Leafless principal branches, bearing homomorphic, linear, sessil, straight basis, decurrent bracts, becoming slightly pointed towards the apex, with a conspicuous central vein. First order branches with leaves disposed in overlapping spirals, with decurrent insertion. Second and third order branches have the same leaf coverage pattern as the first order branches; their apical portions present a globular densification, formed by the whole of the leaves. Leaves are single, with a conspicuous central vein, homomorphic, sessil, bifacial, acicular, slightly falciform, with straight basis, acute apex. From the leafless principal branches, come branches with leaves of morphology identical to the one of the first, second and third order branches, although with scarce and alternate-opposite distribution. At the apical portion of these branches, the leaves gradually transform into bracteal scales, associated to ovuliferous scales. Four ovuliferous scales, located at the final portion of the branch forming a cone. They present decurrent insertion, overlapping but clearly separated edges, with cuneiform basis, biphid apices and smooth edges. Each of the portions of the apices with torsion is elongated into a funicle, with anatropous seed. Cones with 1 (one) level of ovuliferous scales, 4 (four) in the scale verticile and 8 (eight) elliptically elongated seeds, thickened at the central portion.
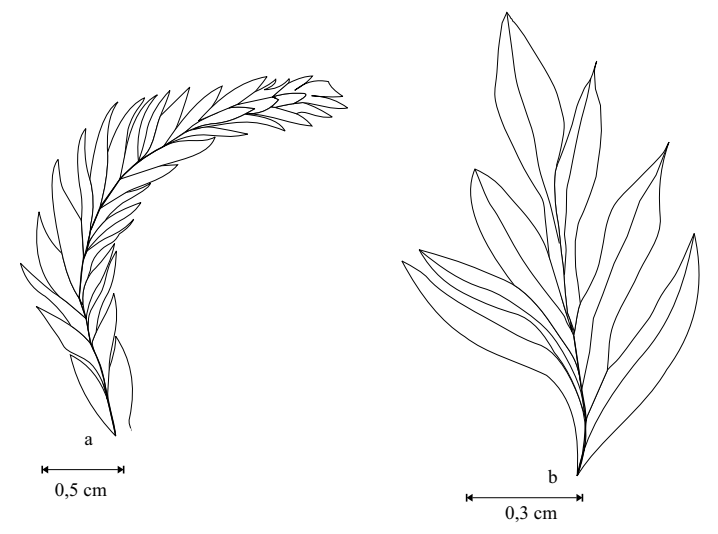

Fig. 2 - Coricladus quiteriensis sp. nov. vegetative branches: (a) apical portion of a branch, demonstrating the disposition of the leaves - PbU 191; (b) apical portion of a branch, demonstrating the conspicuous central vein at the leaves - PbU 136.

\section{DESCRIPTION}

Compounded vegetative branches bearing first, second and third order branching. Leafless principal branches, whose width ranges from 3.36-8.03 mm, bearing, at an angle of $65-70^{\circ}$, bracts which are homomorphic, linear, sessil, with a conspicuous central vein and a straight basis, decurrent, 3.4-20.4 mm long and 0.3-0.9 $\mathrm{mm}$ basis width, becoming slightly pointed towards the apex (Fig. 2b and Fig. 3a and b). First order vegetative branches are $6.1-84.3 \mathrm{~mm}$ long and 2.4-6.5 mm wide, with an insertion angle 

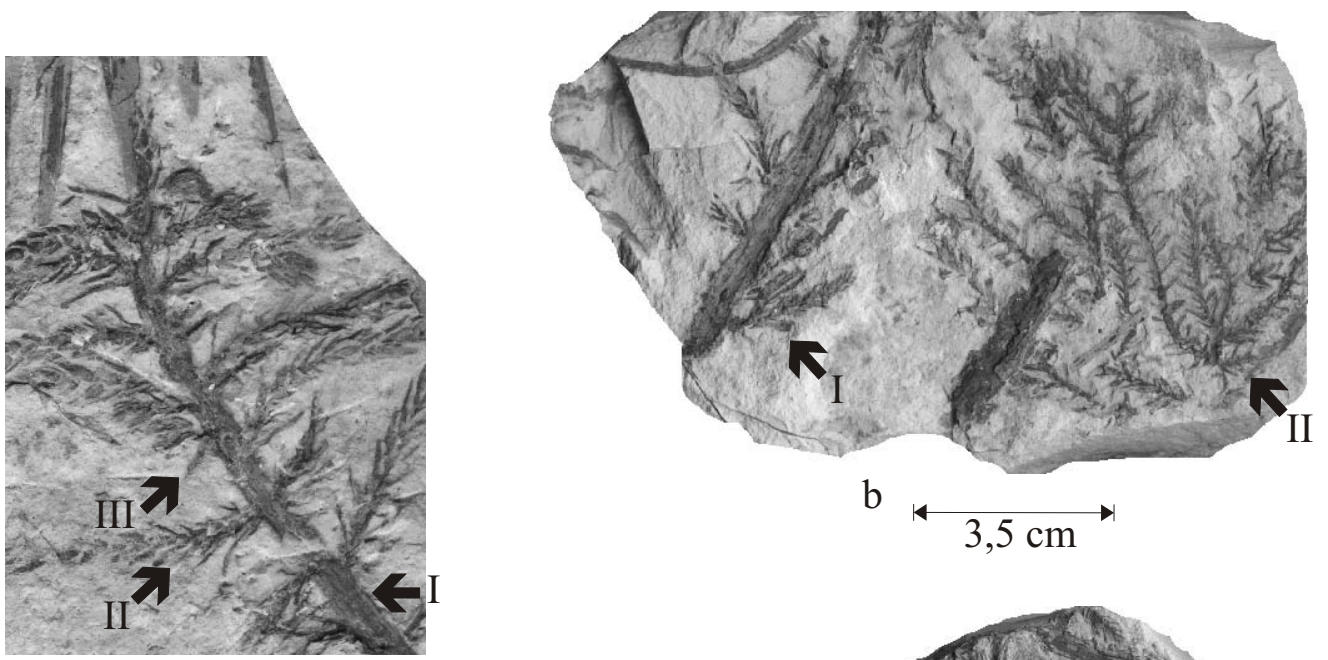

a $1,5 \mathrm{~cm}$
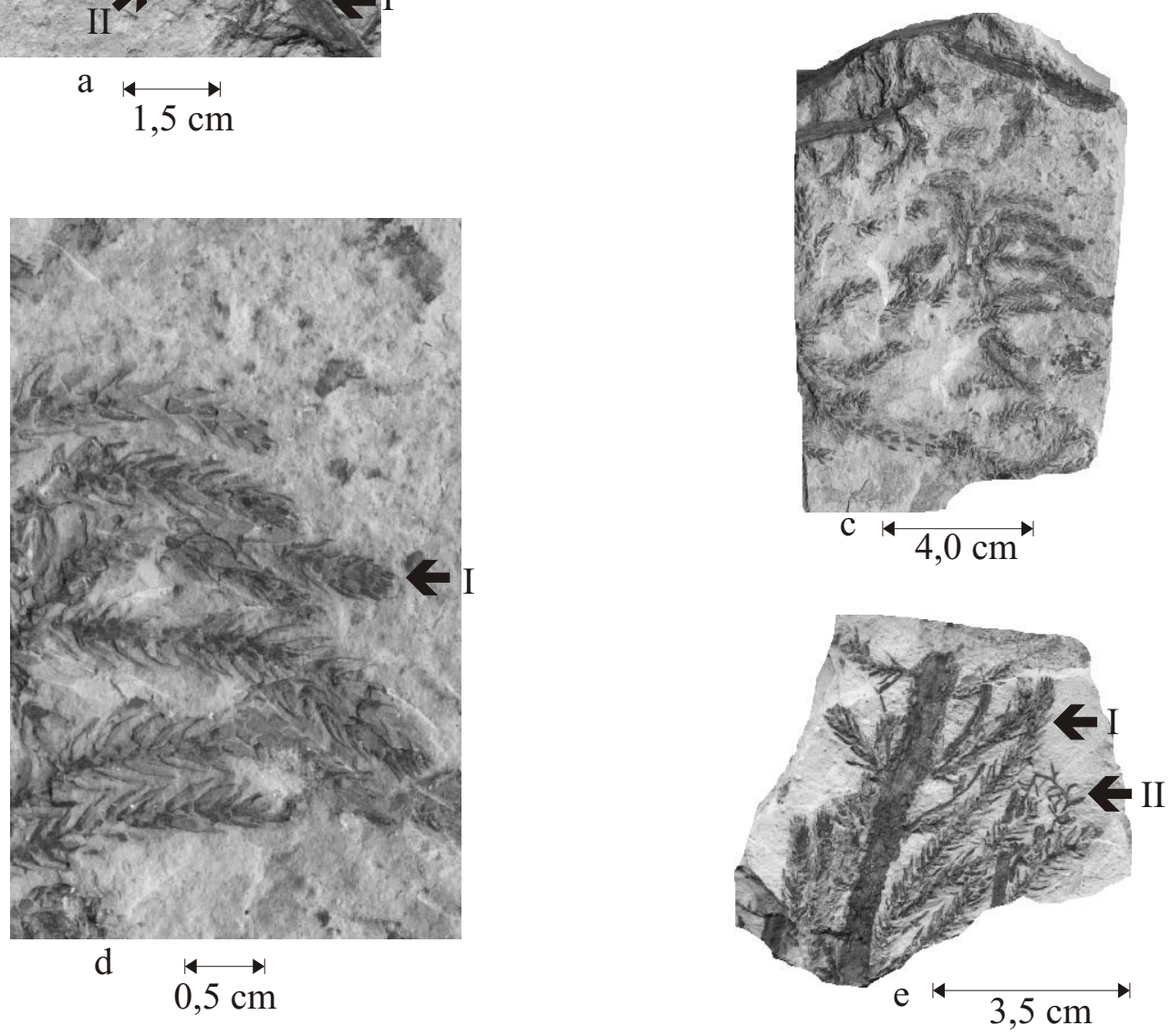

Fig. 3 - Coricladus quiteriensis sp. nov. vegetative branches from Quitéria outcrop: (a) medial portion of a branch, demonstrating the leafless principal branch (I), the distribution of first order branches (II) and of the acicular leaves at its insertion (III) - PbU 226; (b) branches covered with leaves disposed in overlapping spirals, what provides some branches with a more dense coverage (I), but not so dense on others (II) - PbU 417; (c) second and third order branches with the same leaf coverage pattern observed in first order branches - $\mathrm{PbU} 191$; (d) apical portion of the branches, demonstrating a globular densification of the leaves (I), which clearly characterize apical sprouts - PbU 191; (e) vegetative (I) and reproductive (II) branches coming from the leafless principal branch, presenting scarce leaves and cones - PbU 074 (Holotype). 
of $45-60^{\circ}$, covered with leaves disposed in overlapping spirals, with decurrent insertion at an angle 25$45^{\circ}$, what provides some branches with a more dense coverage, but not so dense to others (Fig. 3b). From the first order branches come second and third order branches with 7.5-19.8 mm length and 2.4-4.8 mm width and the same leaf coverage pattern observed in first order branches (Fig. 3c), presenting, in their apical portion, globular densification of the leaves, which clearly characterize apical sprouts (Fig. 3d). First, second and third order branch leaves are single, homomorphic, sessil, bifacial, acicular, slightly falciform, with straight basis and acute apex, 1.8$5.5 \mathrm{~mm}$ long and 0.6-1.1 mm basis width, and with a conspicuous central vein.

From the leafless principal branches come reproductive branches with 5.3-19.7 mm length and 0.7-1.2 mm width, inserted in an angle of $60-70^{\circ}$ and presenting scarce leaves (Fig. 3e, Fig. 4a and b, and Fig. 5a), which are single, homomorphic, sessil, bifacial, acicular, slightly falciform, with straight basis, acute apex, alternate-opposite disposition, with decurrent insertion of $60-90^{\circ}$ angles, $1.3-3.5 \mathrm{~mm}$ apart one from the other, 1.7-2.4 mm length and (0.5-0.9 mm) basis width as well as a conspicuous central vein.

At the apical portion of these branches, leaves are gradually transformed into bracteal scales, associated to ovuliferous scales (Fig. 4c and Fig. 5a,b,c and $d$ ). There are 4 (four) ovuliferous scales, located in the terminal portion of each branch, radially and circular-plane disposed around the axis, forming a cone (Fig. 4d and e, and Fig. 5e and f). These scales present decurrent insertion of $30-80^{\circ}$ angles, with overlapping but clearly separated edges, with laminar and obovate morphology, 2.5-5.1 mm long, 0.4-0.9 mm basis width and 1.3-2.5 mm wide at the central portion (Fig. 4e). The basis are cuneiform, apices are biphid, with sharpened terminal portions, with smooth edges. Each portion of the biphid apices presents a torsion towards its adaxial portion in relation to the branch, elongating and forming a structure that can be related to funicle, where two seeds are adpressed in anatropous posi- tion (Fig. 6). Each cone presents only 1 (one) level of ovuliferous scales totalizing 4 (four) scales and 8 (eight) elliptically elongated seeds, thickened at the central portion, 0.8-1.8 mm long and 0.6-1.0 mm wide at the central portion. On the surface of some samples, some signs of tegument are clearly visible.

\section{DISCUSSION}

The branching pattern (Fig. 7), characterized by: a) the irregular disposition of foliar reproductive branches on a leafless principal branch, forming angles over $60^{\circ}$; b) the presence of leaves with a main vein, acicular-lanceolate, helically attached to the principal branches, forming angles between $60^{\circ}$ and $90^{\circ}$, of first, second and third orders; c) the female reproductive structures characterized by a maximum of four ovoliferous scales, located at the terminal portion of the fertile reproductive branch, showing radial-plane disposition forming a lax cone, are all features quite different from those of other conifers registered in other horizons of several localities in Gondwana realm, at the Permian.

The Buriadiaceae (Seward and Sany) Pant and Nautiyal (1967) show wide distribution in Gondwanaland. This family is represented in Brazilian Lower Permian beds by the vegetative branches of Buriadia heterophylla (Rigby 1972, CazzuloKlepzig and Guerra-Sommer 1983, Bernardes de Oliveira and Yoshida 1981), Buriadia isophylla Guerra-Sommer and Bortoluzzi 1982 (unpublished data), Buriadia mendesi Bernardes de Oliveira 1981, in Bernardes de Oliveira and Yoshida (1981) and Buriadia figueirensis Ricardi-Branco 1998 (unpublished data). The leaves, distinct from those of the specimens of the Quitéria outcrop are simple or forked, linear, single-veined, spirally arranged. Different species are included in a distinct order, Buriadiales by Pant (1982). The female reproductive structures, not registered in the Brazilian sequences yet, are composed by anatropous ovules, developed between the leaves, and solitary cone-shaped structures, are quite different from the material here studied. 

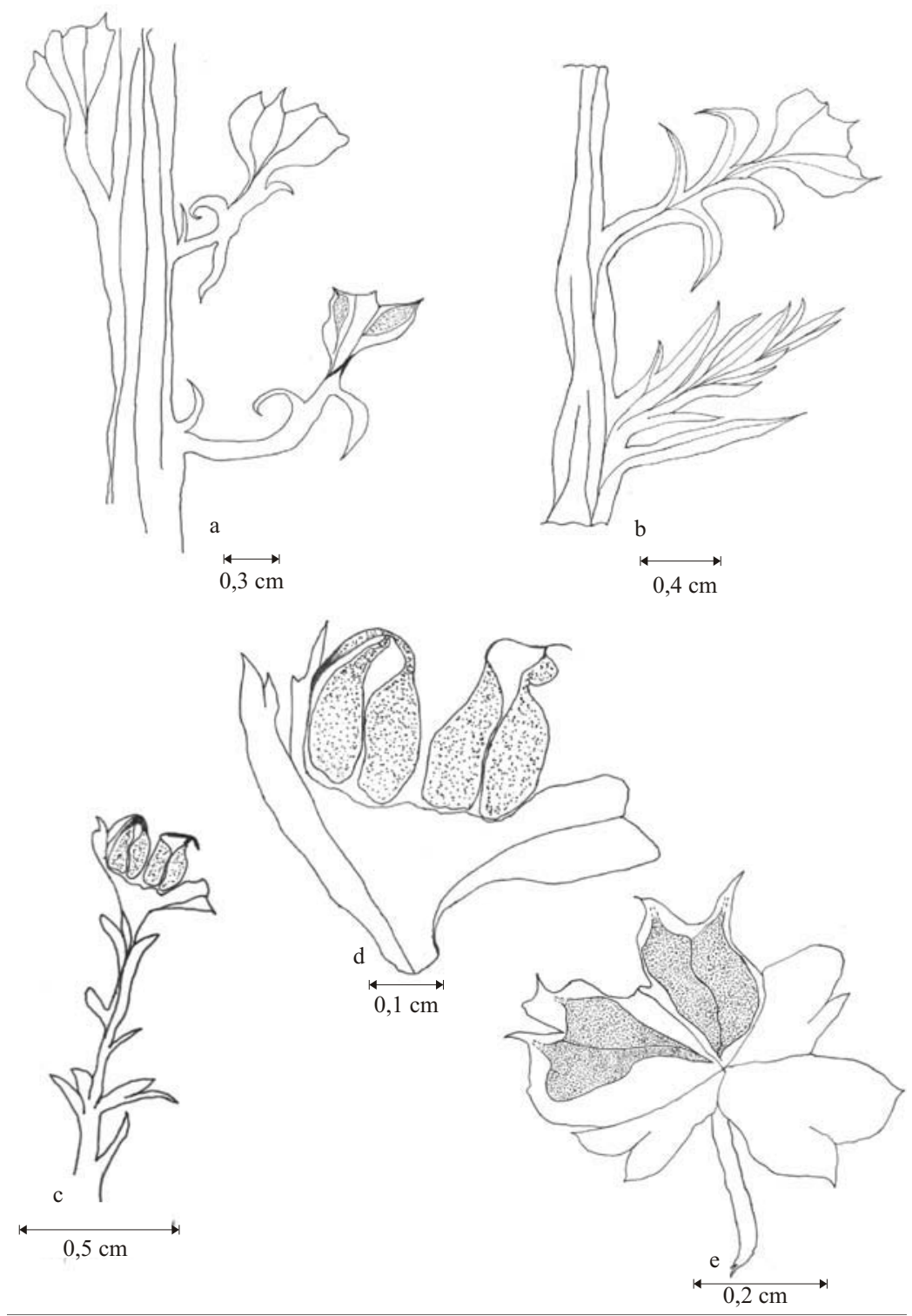

Fig. 4 - Coricladus quiteriensis sp. nov. reproductive branches from Quitéria outcrop: (a) reproductive branches coming from the leafless principal branches, presenting scarce leaves PbU 073; (b) reproductive and vegetative branches, coming from the same leafless principal branch - PbU 075; (c) detail from a reproductive branch with bracteal scales, associated to ovuliferous scales at the apical portion - $\mathrm{PbU} 222$; (d) lateral detail from a cone with seeds - $\mathrm{PbU}$ 222; (e) detail from a cone with 4 (four) ovuliferous scales radially and circular-plane disposed around the axis, with the presence of 4 (four) elliptically elongated seeds (two/scale) - PbU 222.

The genus Paranocladus Florin (1940) is registered in Brazilian Sequences of Paraná Basin with the species: Paranocladus dusenii and
Paranocladus? fallax Florin 1940, in Lower Permian taphofloras of Paraná Basin (Rigby 1972, Millan 1974, Fittipaldi and Rösler 1978, unpub- 


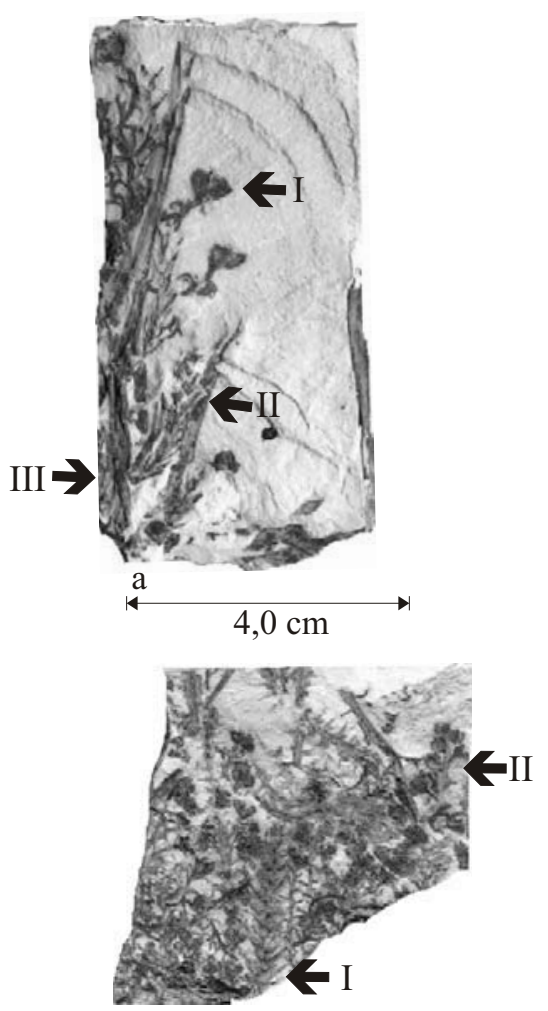

c $\underset{1,5 \mathrm{~cm}}{\longleftrightarrow}$
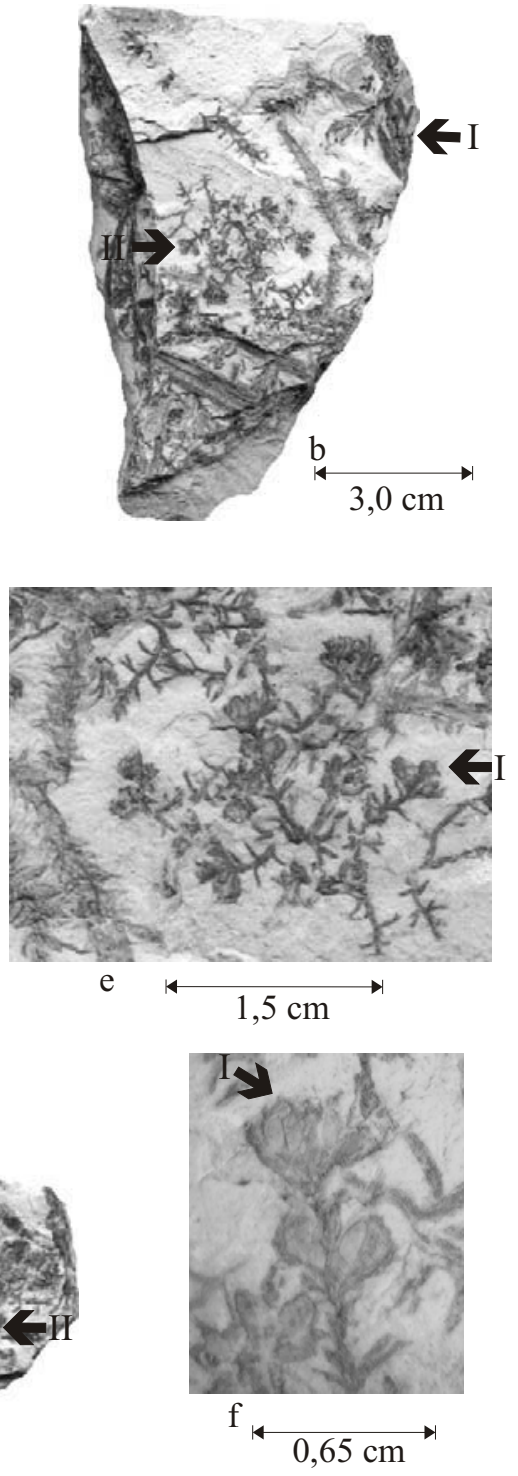

Fig. 5 - Coricladus quiteriensis sp. nov. reproductive branches from Quitéria outcrop: (a) reproductive (I) and vegetative (II) branches, coming from the same leafless principal branch (III) - PbU 073; (b) association of vegetative branches (I) and reproductive branches (II) with bracteal scales, associated to ovuliferous scales at the apical portion - PbU 222; (c) association of vegetative branches (I) and reproductive branches (II) with bracteal scales, associated to ovuliferous scales at the apical portion - PbU 190; (d) association of vegetative (I) and reproductive (II) branches $\mathrm{PbU}$ 057; (e) detail from the reproductive (I) branches - PbU 222; (f) detail from the reproductive branches, with the presence of elliptically-elongated seeds in anatropous position (I) - PbU 222.

lished data). This form genus of leaf reproductive branches, bearing small leaves in a spirally disposition, parallel veined adpressed to the axis, dif- fers from the material here presented. The foliage of Krauselcladus canoinhensis Yoshida 1970 described from Upper Permian Sequences of Paraná 


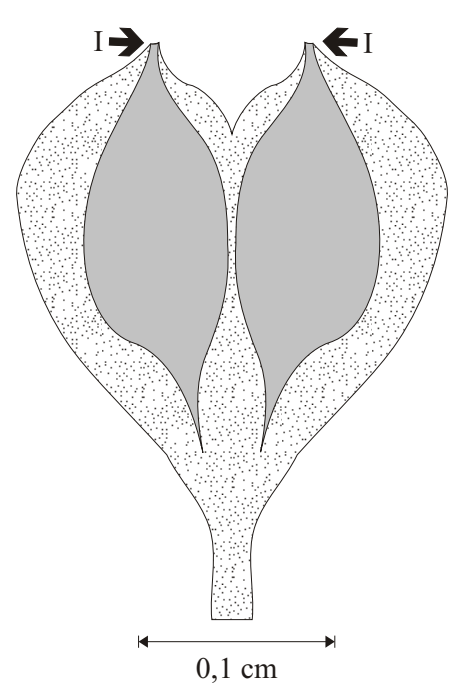

Fig. 6 - Hypothetical reconstruction of the bract-scale complex of Coricladus quiteriensis sp. nov., with the seeds adpressed in anatropous position (I).

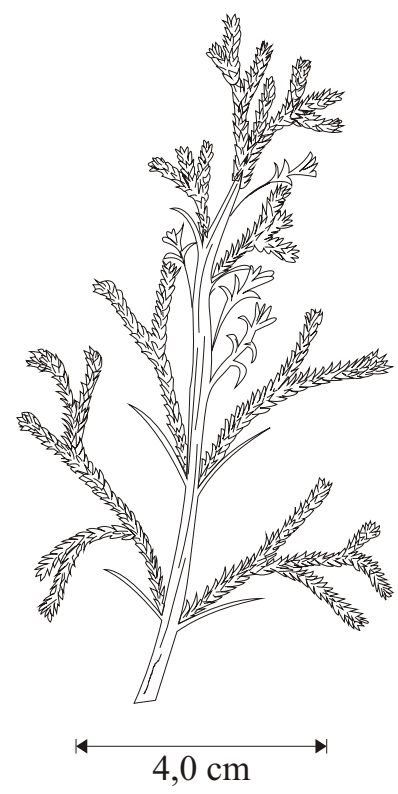

Fig. 7 - Reconstruction of the branching system of Coricladus quiteriensis sp. nov.

Basin (Teresina Formation) presents heteromorphic foliage represented by elongated leaves, midveined, with rounded or biforked apices (Yoshida 1970). These characteristics, similar to Buriadia type, are quite diverse from those of the material of the Quiteria outcrop. Isolated female organs are considered, by indirect association, as related to Krauselcladus reproductive branches. These cones are composed of series of bracts arranged in helically sequences bearing symmetric axillary bracts with seeds, probably orthotropous, in bilateral disposition. All features of both vegetative and reproductive organs are morphologically diverse from the material of Quitéria outcrop.

The genus Brasilocladus Yoshida 1981, in Bernardes de Oliveira and Yoshida (1981) with strongly acicular leaves differs from the morphology of the leaves of the specimens described in this paper. This also happens with the representatives of the genus Paranocladus, which present scale-shaped leaves.

Sterile reproductive branches identified as Walkomiella sp. are registered in Upper Permian Sequences of northern Paraná Basin (Irati Formation) by Ricardi-Branco et al. (1999). The genus Walkomiella, described by Florin (1940) with the type species Walkomiella australis described from Sidney Basin, Australia, and by Walkomiella transvaalensis Le Roux (1963) from Lower Permian of Karoo Basin, is represented by foliage reproductive branches variously branched, with leaves adpressed, imbricate, spirally arranged, rhomboidal with acute apex, leathery. The female cones of Walkomiella australis, described by White (1981) from Australia are compact, composed of a complex of scales and seeds. In Walkomiella indica, Surange and Singh (1951) used a sample of coal coming from Barakar to describe the female cone, composed of seeds in connection to a central axis. Based on these characteristics, it is concluded that the organization of sterile and fertile parts of Walkomiella is different from the material under analysis.

The family Ferugliocladaceae, with the genera Ferugliocladus and Ugartecladus, proposed by Archangelsky and Cúneo (1987) for the Permian of Gondwanan South America (Chubut Province, Tepuel-Genoa Basin) is distinct from Conifer families Walchiaceae, Buriadiaceae and Araucariaceae, and from the material from Quitéria Outcrop. The vegetative reproductive branches, with irregular ra- 
dial branching, with small, lanceolate, single veined, helically disposed leaves, and the female cones composed of a central axis with bracts and orthotropous ovules which are disposed helically, and presenting platyspermic seeds are dissimilar from the specimens here analyzed. Expressive number of dispersed reproductive branches of second order previously attributed to Paranocladus patagonicus Feruglio 1934, proceeding from the same level, where synonymized to Ferugliocladus patagonicus given support to the establishment of the family Ferugliocladaceae.

Comparisons with the genera identified in other provinces of Gondwanaland at the Permian, discussed above, show significant morphological differences.

The sterile foliage of Pagiophyllum from Heer (1881) is mentioned by Anderson and Anderson (1985), as the species Pagiophyllum vandijkii from Upper Permian of South Africa and is represented by reproductive shoots with spirally arranged leaves, contracting gradually from the broad basal cushion, randomly distributed, broader than thick, its length exceeding the width of its own basal cushion. Sterile foliage of the Pagiophyllum type found in organic connection with female cylindrical cones, terminally compact on short branches, composed of forked bracts and cone scales, expanded in lobes bearing inverted ovules, were elements that allowed the identification of Voltziopsis (Potonié) Townrow (1967) referred to Lower Triassic of South Africa. Archangelsky (1996), agrees with Townrow (1967) placing this genus in the family Voltziaceae, which has Euramerican representatives. In the other hand, the specimens here studied, present a singular female cone with only one level of ovuliferous scales, and do not form a cylindrical cone as Pagiophyllum.

The distinctive characteristics of the specimens here analyzed preclude their inclusion in a different conifer family and genus recognized so far. Therefore, it is proposed a new taxonomic unit identified as Coricladus genus with the type species Coricladus quiteriensis.

\section{CONCLUSIONS}

The characteristics presented by the material here studied, despite presenting some morphologic similarity in the vegetative portions with gondwanic forms already described, justified the creation of a new taxon. It is not possible to establish affinities at the family level because the attempts to collect epidermis and pollen fragments were not successful, making it necessary to create a morphogenus. The available data, however, allow suggesting a general morphology reconstitution of Cloricadus quiteriensis.

Archangelsky and Cúneo (1987) suggested two probable phyletic lines for Urgatecladus and Ferugliocladus, based on the structure of the ovuliferous scales and ovules, from a common ancestor, the Walchiaceae. However, the characteristic of the cones found in Coricladus, with 4 (four) ovuliferous scales distributed on a plain level and bearing anatropous ovules, preclude the inclusion of this genus in the same phyletic line as genera Urgatecladus and Ferugliocladus, which present complex cones, with several levels of ovuliferous scales helically distributed, and bearing orthotropous ovules. On the other hand, Buriadia, which presents isolated ovuliferous scales with anatropous ovules, could represent a group phyletically earlier to Coricladus. The present data, however, do not allow proving this hypothesis.

In the Quitéria roof-shale, the large fragments with branches and female cones still connected of Coricladus, suggest that transport was minimal. Their association with stumps of arborescent lycophytes, Botrychiopsis, herbaceous lycophytes and filicopsids suggests that these conifer-plants grew in swampy environments, in a mesophilous to hygro-mesophilous habitat. These inferences are consistent with the hypothesis established by Archangelsky and Cúneo (1987), suggesting that the gondwanic conifers from the Lower Permian, lived in temperate humid conditions, and had a wider range of habitats than those coniferous found in the equatorial belt, which are mainly xerophilous. 


\section{ACKNOWLEDGMENTS}

André Jasper received support from Unidade Integrada Vale do Taquarí de Ensino Superior (UNIVATES), Fundação Nacional de Desenvolvimento do Ensino Superior Particular (FUNADESP), Fundação de Amparo à Pesquisa do Estado do Rio Grande do Sul (FAPERGS) and Coordenação de Aperfeiçoamento de Pessoal de Nível Superior (CAPES), and Margot Guerra-Sommer from Fundação de Amparo à Pesquisa do Estado do Rio Grande do Sul (FAPERGS) and Conselho Nacional de Desenvolvimento Científico e Tecnológico (CNPq).

\section{RESUMO}

Um novo taxon de coníferas (Coricladus quiteriensis) é descrito a partir de fragmentos de megafósseis vegetais do nível de roof-shale do Afloramento Quitéria (Formação Rio Bonito - Permiano Inferior - Sul da Bacia do Paraná - Rio Grande do Sul - Brasil). Esta comunidade megaflorística é incluída na Zona Botrychiopsis Sub-Zona Botrychiopsis valida (Kunguriano/Roadiano). A assembléia, preservada sob forma de impressões, não apresenta registros de caracteres epidérmicos, e é composta por ramos vegetativos isolados, portando folhas aciculares dispostas helicoidalmente, as quais possuem uma nervura central conspícua. Além disso, são registrados ramos férteis com folhas esparsas e irregulares e cones terminais. Ramos principais, áfilos, conectados organicamente a ramos vegetativos e férteis, são raros. Escamas reprodutivas femininas, dispostas em um só plano, estão organizadas em cones terminais, compostos por 4 (quatro) escamas ovulíferas e 8 (oito) sementes anátropas alongado-elípticas. Dados paleoecológicos indicaram um habitat mesófilo a higrófilo, desenvolvido em um ambiente pantanoso.

Palavras-chave: Coricladus quiteriensis, paleobotânica, taxonomia, coniferopsida, Gondwana, Permiano Inferior.

\section{REFERENCES}

Anderson JM And Anderson HM. 1985. Paleoflora of Southern Africa. Prodromus of South African Megafloras: Devonian to Lower Cretaceous. Rotterdam: Balkema, 423 p.

ANDERSON JM, ANDERson HM, ArChangelsky S, Bamford M, Chandra S, Dettmann M, Hill R,
McLoughlin S AND RöSLER O. 1999. Patterns of Gondwana plant colonisation and diversification. J Afr Earth Sci 28: 145-167.

ArChangelsky S. 1996. Aspects of Gondwana paleobotany: gymnosperms of the Paleozoic-Mesozoic transition. Rev Palaeobot Palynol 90: 287-302.

Archangelsky S and Cúneo R. 1987. Ferugliocladaceae, a new conifer family from the Permian of Gondwana. Rev Palaeobot Palynology 51: 3-30.

Bernardes de Oliveira MEC and Yoshida R. 1981. Coniferófitas da “Tafoflora Irapuã”, Formação Rio Bonito, Grupo Tubarão em Santa Catarina. Bol Asocia Latinoam Paleob Palinól 8: 39-55.

Biwas C and Johry M. 1997. The Gymnosperms. Narosa Publishing House, New Delhi, 494 p.

Cazzulo-Klepzig M and Guerra-Sommer M. 1983. Relationship between the Taphoflora of the Itararé Group, Paraná Basin, Southern Brazil and the Permocarboniferous boundary. In: CONG. InTERN STRAT Geol Carb, 10., 1983, Madrid. Compte Rendu 4: 395-402.

Cazzulo-Klepzig M, Guerra-Sommer M, Formoso NL ANd Calarge LM. 2002. Geochemical and palynological evidence for the age determination of Permian coals, southern Brazil. J South Am Earth Sci 15: 375-380.

Della Fávera JC, Chaves HaF, Pereira E, Medeiros MAM and CÂMara Filho LM. 1994. Evolução geológica da sequiência permiana da região de Candiota - RS - Brasil. Acta Geol Leopol 39: 235-246.

Feruglio E. 1934. Fossili liassici della Valle del Rio Genoa (Patagonia). Geologia 9: 1-64.

FitTIPAldi FC AND Rösler O. 1978. Paranocladus? fallax (Conifera). Estudos cuticulares. Bol Inst Geoc USP 9: 109-113.

FLORIN R. 1940. Die Koniferen de Oberkarbons und des Unteren Perms, 5. Palaeontographica 85: 243-363.

Gastaldo RA, Di Michele WA and Pfefferkorn HW. 1996. Out of the Icehouse into The Greenhouse: a Late Paleozoic analog for modern global vegetational change. Geol Soc Am Tod 6: 1-7.

Guerra-Sommer M, Marques-Toigo M and CorrêA DA Silva ZC. 1991. Original bioms and coal deposition in Southern Brazil (Lower Permian), Paraná Basin. Bull Soc Geol Fran 162: 227-237. 
Guerra-Sommer M, Cazzulo-KlepZig M and MeneGAT R. 2001. Roof-shale floras in Early Permian southern Brazilian Gondwana: Evidences of the icehouse waning. Contributions to Geology and Palaeontology of Gondwana in Honour of Helmut Wopfner, p. 231-251.

Heer O. 1881. Contribuitions a la flore fossile du Portugal. Section des Travaux Gelogiques du Portugal, Lisbonne, $51 \mathrm{p}$.

Holz M. 1997. Early Permian sequence stratigraphy an paleophysiography of the Paraná Basin in northeastern Rio Grande do Sul state, Brazil. An Acad Bras Cienc 69: 521-543.

JASPER A AND Guerra-Sommer M. 1998. Licófitas cormofíticas arborescentes do afloramento Quitéria - Formação Rio Bonito (Bacia do Paraná), RS. Pesq 25: 43-60.

Jasper A ANd Guerra-Sommer M. 1999. Licófitas arborescentes in situ como elementos importantes na definição de modelos deposicionais (Formação Rio Bonito - Bacia do Paraná - Brasil). Pesq 26: 49-58.

Jasper A, Guerra-Sommer M, CAzZulo Klepzig M And Menegat R. 2003. The Botrychiopsis genus and its chronostratigraphic implication in Southern Paraná Basin. An Acad Bras Cienc 75: 513-535.

Judd WS, Campbell CS, Kellogg EA and Stevens PF. 1999. Plant Systematics - A Phylogenetic Aproach. Sinauer Associates Inc. Publishers. Massachusetts, $464 \mathrm{p}$.

LE Roux SF. 1963. Walkomiella transvaalensis, a new conifer from the Middle Ecca beds of Vereeniging, Transvaal. Trans Geol Soc South Africa 66: 1-10.

Lopes RDAC AND LAvina EL. 1995. Arcabouço estratigráfico para o intervalo "Rio Bonito-Palermo", (Eo-permiano), entre Butiá e São Sepé, RS. In: SimP sobre Cronoestratigrafia da Bacia do Paraná, 2. Bol Res Expan... Porto Alegre, p. 51-56.

Milani EJ, Faccini UF, Scherer CM, Araújo LM and Cupertino JA. 1998. Sequences and Stratigraphyc hierarchy of the Paraná Basin (Ordovincian to Cretaceous). Sout Braz Bol IG USP, Sér Cient 29: 125-173.

Millan JH. 1974. As sementes platispérmicas do Gondwana face ao esquema Maithy. An Acad Bras Cienc 46: 539-548.
PAnt DD. 1982. The lower Gondwana gymnosperms and their relationships. Rev Paleobot Palynol 37: 55-70.

Pant DD And Nautiyal DD. 1967. On the structure of Buriadia heterophylla (Feist.) Seward and Sahni and its frutification. Phil Tans R Soc London, Ser B 774: $27-48$.

Piccoli AEM, Menegat R, Guerra-Sommer M, MarQues-Toigo M AND Porcher CC. 1991. Faciologia da Sequiência Sedimentar nas Folhas de Quitéria e Várzea do Capivarita, Rio Grande do Sul. Pesq 18: 31-43.

Ricardi-Branco F, Bernardes de Oliveira MEC and Garcia MJ. 1999. Novos elementos tafoflorísticos da Formação Assistência, Subgrupo Irati, Grupo Passa Dois, bacia do Paraná, provenientes de Angatuba (SP), Brasil. Rev Un Guar Geociências 6: 85-95.

Rigby JF. 1972. The Upper Paleozoic flora at Lauro Müller, Santa Catarina, southern Brazil. An Acad Bras Cienc 44: 279-293.

Stewart WN and Rothwell GW. 1993. Paleobotany and the evolution of plants. Cambridge University Press, Cambridge, $521 \mathrm{p}$.

Surange KR And Singh P. 1951. Walkomiella indica, a new conifer from the Lower Gondwana of India. J Indian Bot Soc 30: 143-147.

TAYlor TN AND TAYlor EL. 1993. The Biology and Evolution of Fossil Plants. New Jersey, USA. Prentice-Hall, $982 \mathrm{p}$.

Townrow JA. 1967. On Rissikia and Mataia podocarpaeous conifers from the Lower Mesozoic of southern lands. Proc R Soc Tasmania 101: 173-188.

White ME. 1981. The cones of Walkomiella australis (Feistm.) Florin. The Palaeobotanist 28-29: 75-80.

WNuk C. 1996. The development of floristic provinciality during the Middle and Late Paleozoic. Rev Palaeobot Palynol 90: 5-40.

Yoshida R. 1970. Novo gênero de conífera da Formação Estrada Nova, Norte do estado de Santa Catarina. Bol DNPM, Div Geol Miner 249: 1-17. 